\title{
Máscara, corpo e cidade: fricções de uma reescritura cênica
}

\section{Mask, body and city: frictions of a scenic rewrite}

Alexandre Borin Antunes ${ }^{1}$

Inês Alcaraz Marocco ${ }^{2}$ 


\section{Resumen}

Este texto aborda o trabalho de mascaramento do ator e a sua relação entre máscara, jogo do ator e a cultura urbana local, discutindo a reverberação de suas potencialidades cênicas junto ao movimento de urbanização da cidade de Porto Alegre. A expressão mascaramento caracteriza-se por ser 0 ato ou efeito de mascarar-se, e se deriva do termo máscara, que por sua vez tem origem na palavra italiana maschera, que denota ornamento de disfarce. Ela é aqui utilizada para designar o trabalho do ator em cena como um ato de passagem de sua identidade cotidiana à uma outra, expressiva e ficcional, utilizando-se de princípios técnicos de movimentos e de ações físicas do ator.

Palavras-chave: Máscara; arte de ator; espaço urbano; corpo; intervenção urbana

\section{Abstract}

This text is about the masking work of the actor and its relationship between mask, actor 's play and local urban culture, discussing the reverberation of its scenic potential with the urbanization movement of the Porto Alegre city. The term masking is characterized by the act or effect of masking itself, and is derived from the term mask, which in turn originates from the Italian word maschera, which denotes disguise ornament. It is here used to denote the actor's work on the scene as an act of passing from his everyday identity to another, expressive and fictional, using technical principles of movements and physical actions of the actor.

Keywords: Mask; actor art; urban territory; body; urban intervention 
O interesse pelo mascaramento do ator, aqui entendido como o acesso a outras formas de expressão diferentes do cotidiano - através da transposição de diferentes tonicidades e qualidades corporais como a retração, peso, leveza, expansão ou dilatação muscular, com ou sem o uso do objeto máscara na criação e composição de personagens - se fez presente desde cedo em meus estudos em teatro, e cresceu gradualmente. Partindo do estudo em mimese corpórea ${ }^{3}$, na pesquisa em Iniciação Científica intitulada Sujeitos em estado de representação fundamentando uma técnica de criação para o ator teatral (2007 - 2010), sob a coordenação da professora Cristiane Werlang, durante os primeiros anos de minha graduação no curso de Teatro no Departamento de Arte Dramática (UFRGS) onde analisávamos o gesto e a corporeidade de contadores de causos como objeto de estudo, para posteriormente recriá-los teatralmente em sala de ensaio -, cresce o interesse pelas diferentes formas de expressão do corpo em cena e pelos meios que estruturam a ação cênica, as quais foram aprofundadas em minhas buscas e práticas teatrais. Assim foi com a pesquisa no estilo teatral do Bufão nas montagens do espetáculo de rua Meu Barraco, Minha Vida em 2009, com direção de Eve Mendes ${ }^{4}$ e de O Estranho Cavaleiro em 2013 (texto de Michel de Ghelderode ${ }^{5}$ ), com direção de Irion Nolasco ${ }^{6}$. Participei também de outros trabalhos onde os estilos trabalhados foram o Melodrama e a Farsa. Nestes dois processos de montagem cênica trabalhamos o texto A Serpente de Nelson Rodrigues: a primeira montagem para o palco, com direção de Irion em 2009 - se desenvolveu tendo o estilo teatral do Melodrama como referência - e a segunda foi elaborada como um espetáculo de rua utilizando-se do gênero da Farsa, intitulada $A$ Serpentina ou meu amigo Nelson, com direção de Eve em 2010.

Tais montagens me aproximam da presente pesquisa em Mestrado, cujo objetivo é investigar o jogo do ator por meio do uso de Máscaras Expressivas do tipo inteira na rua - máscaras que possuem expressões humanas bem definidas e que denotam estados de animação e de caráter, podendo ser meia ou inteira -, através dos princípios do foco, interesse, ação, reação e triangulação: princípios utilizados desde a pedagogia de Jacques Copeau ${ }^{7}$ e Jacques Lecoq $^{8}$ e difundidos até os dias de hoje por meio de seus discípulos espalhados pelo mundo, porém nomeados de diferentes formas. Neste trabalho, as designações que utilizo são as mesmas empregadas por

3 O LUME - Núcleo interdisciplinar de pesquisas teatrais da Unicamp, prefere usar esta palavra ao invés de imitação, para designar suas pesquisas nessa área, pois ela pode sugerir uma imitação estereotipada e estilizada da pessoa. "Não é esse o objetivo. Buscamos uma imitação precisa e real, sim, não só da forma e da fisicalidade, mas principalmente das corporeidades das pessoas. Na verdade, uma definição mais precisa seria algo como 'equivalências orgânicas de observações cotidianas', pois busca imitar não somente os aspectos físicos, mas também os orgânicos, encontrando equivalências para esses últimos". (Ferracini, 2001, p.187)

4 Eve Mendes é atriz, diretora e atualmente doutoranda em cotutela de tese entre o Programa de Pós-Graduação de Artes Cênicas da UFRGS e Université d'Aix-Marseille (França).

5 Michel de Ghelderode (1898 - 1962) foi um dramaturgo belga de vanguarda. Em seus textos geralmente são explorados os limites da vida material humana, abordando temáticas de cunho macabro, como a morte, e de devoção sacra.

6 Irion Nolasco é mestre em Esthétique, Sciences et Technologie des Arts - spécialité Études Théâtrales et Choréographiques - pela Université de Paris VIII (1991) e Master of Arts - Speech and Drama pela University of Kansas (1980). Foi professor do Departamento de Arte Dramática da UFRGS, atuando principalmente nos seguintes temas: direção teatral, construção de personagem, arte do ator, energias corporais e improvisação teatral. Atualmente, é diretor artístico da Satori Associação Teatral.

7 Jacques Copeau (1879 - 1949) foi um professor, diretor, dramaturgo francês e fundador do Théâtre du Vieux-Colombier em Paris, foi precursor, no ocidente, na criação de uma pedagogia da máscara para o treinamento do ator

8 Ator e professor de arte dramática, Lecoq (1921 - 1999) desenvolveu seu próprio método de treinamento de atores. Partindo de sua experiência como educador físico e esportista, interessa-se pelo corpo como instrumento de expressão e interpretação. Fundou a Escola Internacional de Teatro Jacques Lecoq em Paris em 1956. 
Tiche Vianna ${ }^{9}$, que ao longo dos mais de trinta anos de pesquisa com a máscara, tem se dedicado à pedagogia e criação com a máscara teatral. Por meio dos princípios citados o ator exercita a focalização da atenção em determinado corpo ou objeto, interessa-se por ele, age em sua relação, reage de acordo com a ação desencadeada e compartilha sua reação com o público ou com quem está em cena. Este compartilhar é chamado aqui de triangulação e é realizado por meio do direcionamento corporal do ator. As reações são dadas a partir de mudanças musculares como retração, expansão, peso e leveza, e são capazes de representar diferentes sentidos e significações aos acontecimentos. É um esquema pedagógico que trata de compreender fisicamente a organicidade desse corpo em jogo teatral e suas formas de afetação. Estou falando aqui do corpo material em unidade com sua dimensão sensorial, atravessado e constantemente contaminado pelo sentir, por onde identificam-se os aspectos aqui entendidos como de mascaramento no trabalho do ator.

Em Meu Barraco, Minha Vida e em Estranho Cavaleiro - duas montagens distintas realizadas em diferentes grupos de trabalho - foi feita a aproximação do território dramático do Bufão: o primeiro espetáculo feito na rua e o segundo em palco de arena. O bufão, que tem sua origem na Idade Média, era aquele que através da sua loucura podia dizer as verdades. "Ele era uma figura visionária, à margem da sociedade" ${ }^{10}$ Marocco, 2014). Caracteriza-se por suas deformidades físicas, que evidenciam suas diferenças em relação às outras pessoas. Ambas montagens exploraram o grotesco e a deformidade física e moral desses corpos - alguns dos princípios que constituem o estilo Bufão e que caracteriza o mascaramento do ator, conforme relata Jacques Lecoq:

Por meio dessa transformação corporal, nesse corpo reinventado e artificial, de repente eles se sentiam mais livres. Ousavam fazer coisas que jamais teriam feito com seus próprios corpos. Nesse sentido, o corpo inteiro tornava-se máscara. Diante desses corpos bufonescos, os personagens parodiados aceitavam mais facilmente que "loucos" zombassem deles. (Lecoq, 2010, p. 180 e 181)

O bufão zomba, parodia, caçoa, mas o faz a partir de sua própria condição grotesca, de sua máscara corporal. Isso dá ao bufão a dimensão do louco, que subverte a ordem comum, e, portanto, não participa dela, possibilitando dizer e agir, livre dos julgamentos da ordem social vigente. Nessa liberdade sarcástica, e também em sua humanidade, encontra-se o jogo do ator, que se expande e torna-se mais perspicaz sob o corpo do bufão, tanto em sala convencional como na rua. Mas é no contato direto com o público, portanto na rua, que sua dinâmica se evidencia e se desenvolve, uma vez que a marginalidade do bufão encontra eco neste ambiente: lugar onde a desigualdade e a exclusão - sofridas também por ele - são escancaradamente visíveis.

Na montagem de Meu Barraco, Minha Vida sete bufões são desalojados de suas moradias e saem em busca de um lar pelas ruas, sendo acompanhados pelo público em seu trajeto itinerante. $O$ bando de bufões iniciava sendo enxotado de um estabeleci-

9 Tiche Vianna (1964) é pedagoga da máscara e diretora do grupo Barracão Teatro (Campinas). Especializada na transposição, para o Brasil, do universo italiano das máscaras.

10 Afirmação feita pela diretora e professora Dra. Inês Alcaraz Marocco, ao comparar o dramaturgo gaúcho Qorpo-Santo (José Joaquim de Campos Leão) à figura do bufão da Idade Média. (Fonte:.http://teatrojornal.com.br/2014/06/bufao-do-seculo-xix/) 
mento e logo todos desciam rolando a ladeira da rua General Câmara, no centro de Porto Alegre, para lá embaixo cantar o hino nacional do Brasil. De caráter popular, a montagem evidenciava a marginalização do bufão, pondo seu conflito em relação aos moradores de rua, negligenciados e constantemente expulsos de seus locais de habitação. Estes moradores de rua muitas vezes se uniam ao bando, acompanhando-nos e compondo uma estrutura cênica liminar entre real e ficção, práxis cotidiana e teatral, mesclando o riso ao caráter de denúncia ora proposto.

Já no espetáculo de rua $A$ Serpentina ou Meu Amigo Nelson, a referência principal era a Farsa e o carnaval. A Farsa é aqui entendida como gênero dramático ou literário que se utiliza de elementos cômicos e burlescos no desenvolvimento de seus enredos. As situações geralmente abordadas nas obras deste gênero referem-se ao cotidiano familiar e comercial, como nas feiras. Caracteriza-se por seus personagens e situações caricatas, que não pretendem seguir a verossimilhança dos costumes tampouco questionar valores sociais (Bravo e Whitaker, 2015). Nessa montagem buscou-se uma integração do corpo festivo carnavalizado às temáticas populares propostas no texto de Nelson, como o adultério, a violência, sexo e morte. Essa integração foi ao encontro à uma qualidade corporal que dava grande importância ao baixo ventre, ou seja, região pélvica do corpo, ligado à esperteza, agilidade, sexualidade e necessidades fisiológicas. O corpo, neste contexto, é o do ser humano em sua essência, onde o instinto e o desejo se mesclam e mostram-se presentes por meio de seus impulsos corporais, enfatizando ao mesmo tempo o caráter cômico e popular da montagem. Aqui, assim como no Bufão, há a predominância do elemento grotesco, porém mais ligado às formas exageradas dos corpos e suas ações no contexto do carnaval. Nesta conjuntura, os corpos das personagens apresentam deformações nos seios, coxas e genitais, sendo ornados de cores, fitas e elementos carnavalescos, acentuando, assim, a conotação sexual e festiva destes corpos. Tais concepções tinham o intuito de aproximar o espetáculo à uma abordagem popular e da vida material e corporal, tal como afirma Bakhtin (1987, p.34):

O grotesco, integrado à cultura popular, faz o mundo aproximar-se do homem, corporificando-o, reintegrando-o por meio do corpo à vida corporal (diferente da aproximação romântica, totalmente abstrata e espiritual). No grotesco romântico, as imagens da vida material e corporal: beber, comer, satisfazer necessidades naturais, copular, parir, perdem quase completamente sua significação regeneradora e transformam-se em "vida inferior".

Esta abordagem festiva dos elementos grotescos, foi de encontro às temáticas densas e obscuras tratadas na obra de Nelson, como o adultério e a morte: temas presentes no texto original $A$ Serpente, tomado aqui como referência para as montagens. $\mathrm{Na}$ peça, as irmãs Guida e Lígia, e seus respectivos maridos, moram em um mesmo apartamento. Lígia (a irmã mais nova, recém-casada com Décio), revela para sua irmã mais velha que ainda é sexualmente virgem e que está infeliz em seu casamento. Após ser agredida e abandonada por Décio, Lígia, em seu desespero, tenta se matar. Guida flagra sua irmã nesta tentativa, e depois de discussões a respeito de seus conflitos e intimidades, tem a ideia de oferecer seu marido Paulo para passar uma noite com Lígia. O acontecimento provoca uma série de conflitos que revelam obsessões e desordens 
morais das personagens, culminando em uma cadeia de acontecimentos decorrentes desse problema, como a traição e a morte de Guida: empurrada pelo próprio marido do alto de um prédio.

Os textos de Nelson Rodrigues são ricos em mitos e arquétipos. O texto A Serpente, classificado pelo escritor, crítico, professor e ensaísta mineiro Sábato Magaldi (1927 2016) como uma Tragédia carioca, - última peça escrita por Nelson - apresenta referências ao mito ${ }^{11}$ da serpente no Jardim do Éden ${ }^{12}$, no momento em que Guida oferece à irmã o fruto do conhecimento do prazer, estimula sua desobediência em ter acesso ao sexo por meio de seu cunhado. Ao aceitar a proposta de Guida, tanto Lígia como Paulo comem do fruto proibido do conhecimento daquilo que é bom e ruim, e são expulsos do paraíso: Lígia deixa o paraíso da inocência, e Paulo o paraíso da fidelidade. A partir desta consumação, Guida passa a ser temida assim como a serpente do Éden e precisa ser eliminada (Rocha, 2004).

Em A Serpentina, nome dado ao espetáculo de rua, a trama desenrola-se em um cortejo de carnaval, que mistura marchinhas clássicas e canções contemporâneas do brega ao pop - no espaço urbano. E é neste espaço - atravessado por gente, cores, vozes, onde a pluralidade habita - que a referência farsesca se apresenta por meio de elementos cômicos presentes nas situações e no jogo do ator, como: a presença de um falo gigante no personagem Paulo (considerado a representação do macho na sociedade machista e patriarcal); a ação de descer e subir uma escada imaginária utilizando desníveis ascendentes na caminhada ao subir a escada, e descendentes ao descer; a queda e morte da personagem Guida do alto de um prédio (representado em ação lenta e contínua de cair de um cubo), e outros elementos que caracterizam o corpo e o jogo da cena com qualidades próximas a linguagem farsesca, aqui também entendidas como componentes do mascaramento do ator.

Além dos espetáculos de rua, relaciono a ideia de mascaramento também ao trabalho do ator em teatro convencional, como na montagem de A Serpente, com direção de Irion. Neste espetáculo, com a utilização do mesmo texto anteriormente citado, o estilo teatral do Melodrama - compreendido como um estilo da efervescência das grandes paixões humanas, com interpretação de caráter forte e realista - foi uma das referências para a construção do jogo entre os atores e atrizes do elenco. Para isso, um dos aspectos de tal estilo presentes no processo foi o reconhecimento dos grandes sentimentos presentes no texto dramático de Nelson, tais como: o bem e o mal, a moral, a inocência, o sacrifício e a traição. No Melodrama, "o objetivo é chegar a uma interpretação suficientemente forte para que, a partir da expressão desses grandes sentimentos, os espectadores sejam levados às lágrimas" (Lecoq, p.164). Esses sentimentos foram trabalhados por meio de ações físicas que buscavam uma dimensão ampliada do gesto, porém não na esfera da paródia, mas na busca pela verdade - conforme a afirmação de Lecoq acima - que pudesse ressaltar os aspectos específicos da natureza e paixões humanas propostas na dramaturgia do autor.

\footnotetext{
11 Relação estabelecida Francisco C. da Cunha em seu livro Nelson Rodrigues Evangelista, 2000.

12 No relato judaico-cristã, o Jardim do Éden é o local onde ocorreram os eventos narrados no Livro do Génesis (Gen., 2 e 3), "onde é narrada a forma como Deus cria Adão e Eva. A ordenança dada por Deus seria a de que o Homem podia comer os frutos de todas as árvores do bem do jardim, exceto os da árvore do conhecimento do que é o bem e do que é o mal. Ao desobedecer esta ordenança e comer esse fruto proibido, Adão e Eva ficam a conhecer o bem e o mal, e do pecado nasceu a vergonha e o reconhecimento de estarem nus. Em resultado da desobediência, Deus expulsa o homem do jardim." (Fonte:https://books.google. com.br/books?isbn=8566276094)
} 
Além disso, buscou-se o aspecto mitológico do texto e da encenação, estudo realizado primeiramente por Magaldi, que categorizou as obras de Nelson como Tragédias Cariocas, Peças Míticas e Peças Psicológicas, aproximando tais obras - antes consideradas vulgares e obscenas - ao mito e a cultura teatral erudita, conforme já citado anteriormente no texto.

As apresentações ocorreram em sala de teatro convencional, o que possibilitou o uso de recursos de iluminação e composição sonora como elementos potenciais da linguagem, como a trilha do compositor brasileiro Heitor Villa-Lobos, acentuando o aspecto genuinamente brasileiro por meio das nuances populares presentes nas obras do compositor. Neste caso os aspectos do jogo estavam presentes no ato cênico em teatro convencional, e não diretamente com o público como nas montagens de rua. Porém o exercício da construção de um corpo a partir da referência do melodrama - buscando dar ênfase aos conflitos propostos pelo autor - tornaram-se "máscara" no corpo do ator, uma vez que transcendiam a identidade do corpo cotidiano por meio de características como qualidades gestuais dilatadas e distorção moral das personagens, conferindo outro funcionamento da lógica de ação proposta.

Os trabalhos mencionados tinham em comum o interesse em investigar territórios teatrais específicos, tais como o Bufão, Farsa e Melodrama. Suas relações com o jogo do ator se estabelecem por meio do mascaramento que este constrói em seu corpo e que impulsiona formas de agir específicas a partir da aproximação com cada estilo teatral. Em decorrência destas investigações e experiências artísticas, dentro e fora da universidade, e dos resultados obtidos nas produções realizadas, passei a me interessar pelas relações do trabalho do ator e suas possibilidades de jogo a partir do contato com a cultura urbana nas ruas da cidade de Porto Alegre, reconhecendo o aspecto do mascaramento como um ato de transformação física, como elemento potencialmente expressivo no contato com a cultura popular.

Ao me aproximar dos territórios dramáticos do Melodrama, Bufão e variedades cômicas com elementos burlescos e absurdos como o da Farsa, nos diferentes processos cênicos citados, onde o ator se utiliza de formas de mascaramento - o apoio da bibliografia de Jacques Lecoq sobre o assunto foi de suma importância para o entendimento de tais estilos, e essencial na investigação e criação de tais mascaramentos e suas relações. Seu interesse e dedicação em investigar o corpo expressivo e suas possibilidades de transposições e atitudes, o levou a fundar a Escola Internacional de Teatro Jacques Lecoq (França, 1956), afim de sistematizar suas pesquisas. Empenhado em descobrir e pesquisar os meios de engajamento do corpo afim de torna-lo disponível ao jogo e às diferentes linguagens cênicas, Lecoq desenvolve um sistema de trabalho para o ator, entrelaçando sua experiência como ator e profissional do mimo aos conhecimentos como esportista e professor de educação física: experiência que desperta o desejo em investigar o movimento do corpo e suas possibilidades expressivas e criativas na cena, tal como afirma Lecoq quando diz que "a Escola privilegia a interpretação criativa, o jogo, mais do que a interpretação convencional [...]" (Lecoq, 2010, p. 234). Para ele o trabalho do ator se fundamenta no físico, ou seja, por meio de treinamentos que predisponham o corpo cotidiano à outras possibilidades de movimento e de ação no espaço cênico.

No território do Bufão em Meu Barraco, Minha Vida - com a proposição da direção - passamos a praticar exercícios indicados na pedagogia de Lecoq, com o intuito 
de compreender a lógica de suas abordagens. Considerando isso, as investidas realizadas nestas aproximações tinham o intuito de reconhecer os princípios e lógicas de ação do Bufão, para então, a partir disso, possibilitar o jogo do ator. Neste jogar, os elementos técnicos exercitados em cada linguagem deram suporte à criação da dramaticidade cênica na rua, tornando os corpos atuantes os próprios criadores da dramaturgia da cena, realizada por meio das improvisações dos atores.

Embora nenhuma destas montagens e práticas cênicas tivessem o objeto máscara sobre o rosto do ator, reconheço nelas o desejo latente de investigar suas possibilidades expressivas para além do usual ou cotidiano, para outra corporeidade, ou seja, para formas e qualidades corporais capazes de acessar diferentes imaginários e distintas formas de se expressar: o mascaramento do corpo.

Ficará claro, $[\ldots]$ que a máscara contribui para a formação essencial do ator, porque ela não permite a mentira e revela todas as suas fraquezas: falta de imaginação, mais fazer do que ser, falta de presença, falta de escuta. [...]. Ela expõe aquele que não quer entrar no jogo e que se serve dela para se esconder. Inversamente, a máscara pode tornar-se sublime e permitir momentos de teatro de rara intensidade. (Mnouchkine apud Féral, 2010, p. 64 e 65)

Dessa forma, tal mascaramento também se encontra na busca pela expressividade. Diretores como Ariane Mnouchkine ${ }^{13}$, Inês Marocco ${ }^{14}$ e Tiche Vianna, utilizam a máscara como uma ferramenta de trabalho a partir de seus princípios fundamentais, entendidos como importantes meios de acesso e treinamento do jogo do ator. Nesse aspecto, as montagens cênicas Meu Barraco, Minha Vida, A Serpente e A Serpentina ou Meu Amigo Nelson, anteriormente referidas, aproximam-se daquilo que mais tarde encontrei no trabalho de atuação com a Máscara Expressiva, em que a articulação entre o corpo e a máscara implicaria em entender uma lógica específica de funcionamento, a partir de princípios como o do foco, interesse, ação, reação e triangulação: princípios de atuação presentes no trabalho com a máscara e no jogo do ator, que buscam evidenciar seu funcionamento cenicamente.

A busca por esta unidade e pelo estudo do gesto e suas transcrições corporais conduziu minhas pesquisas e práticas como ator e me aproximou de territórios teatrais com pedagogias gestuais e expressivas diferentes e específicas. Apesar de suas diferenças elas se constituem por mascaramentos que se manifestam no corpo e se relacionam de diferentes formas entre si e com o espectador. Aqui, a máscara expressiva referida é confeccionada e utilizada pelo grupo Máscara EnCena ${ }^{15} \mathrm{com}$ a orientação de Fábio Cuelli - ator e instrutor de confecção de máscara do referido grupo. Essas máscaras apresentam aspecto humano, do tipo inteira e com linhas que se mostram de forma anatômica e arredondada, ao contrário de máscaras expressivas com linhas e formas mais sulcadas e alinhadas como as de Lecoq, confeccionadas

\footnotetext{
13 Ariane Mnouchkine (França - 1939) é diretora de teatro e cinema francesa, fundadora do Théâtre du Soleil em Paris (1964), coletivo teatral que se instala na Cartoucherie de Vincennes em 1970.

14 Inês é professora da Universidade Federal do Rio Grande do Sul e diretora artística do Grupo Cerco. Possui doutorado em Esthétique, Sciences et Technologie des Arts pela Université de Paris VIII (1997). Também tem formação pela École Internationale de Théâtre, Mime et Mouvement de Jacques Lecoq (1983/1985) e pelo Laboratoire d'Études du Mouvement (1993/1994).

15 Grupo formado em 2014 pelos artistas Alexandre Borin, Camila Vergara, Fábio Cuelli e Mariana Rosa na cidade de Porto Alegre, com o intuito de investigar e desenvolver práticas cênicas e pedagógicas a partir da máscara teatral.
} 
por Sartori ${ }^{16}$, utilizadas para o treinamento de atuação ou pré-expressivo - o que imprime outro tipo de expressividade e corporeidade.

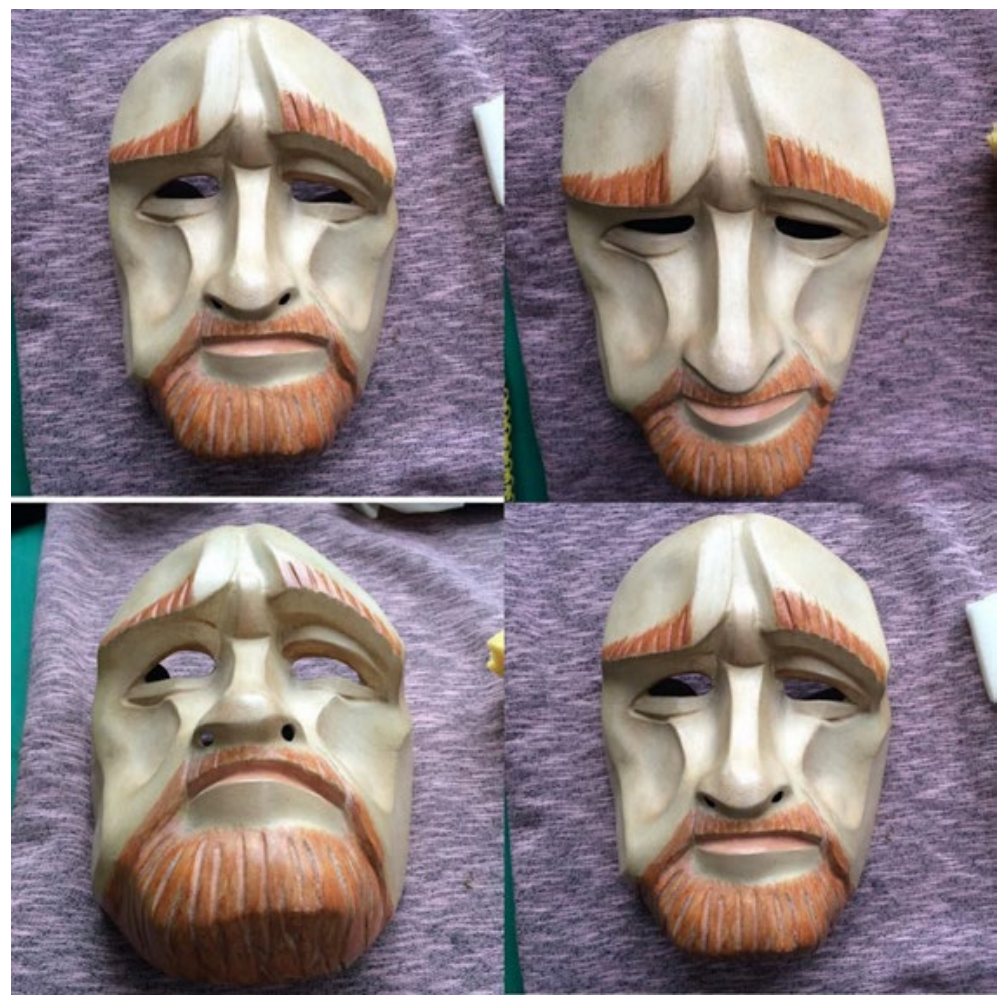

Máscaras Expressivas confeccionadas por Donato Sartori

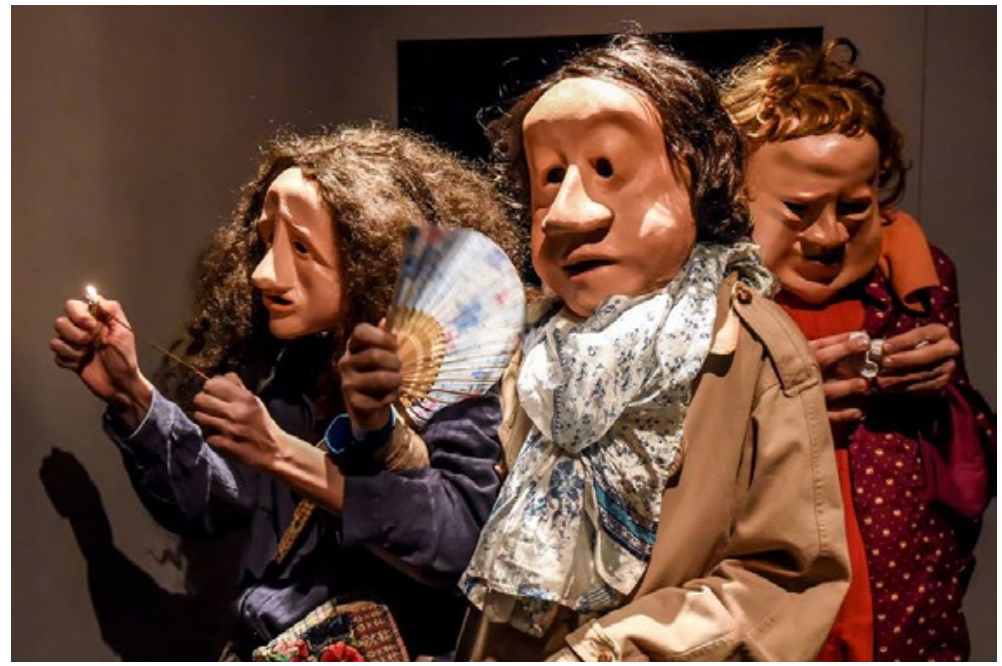

Máscaras Expressivas confeccionadas pelo grupo Máscara EnCena e utilizadas no espetáculo Imobilhados, com direção de Liane Venturella ${ }^{17}$. Foto: Claudio Etges

Nesse sentido, cabe reforçar que cada detalhe expressivo impresso na confecção da máscara e em sua transcrição corporal é importante, posteriormente realizada pelo trabalho do ator. É este rastro impresso na, e pela máscara, que dá os pontos de referência para o ator desenvolver o corpo e a lógica da personagem, seja seguindo ou contrariando suas linhas expressivas: trabalho conhecido como contramáscara. Neste

16 Escultor e mascareiro italiano - termo oriundo do italiano mascheraio, que se designa a quem se dedica ao ofício de produzir máscaras. Filho do célebre escultor Amleto Sartori, herdou os ensinamentos de seu ofício.

17 Atriz e Diretora gaúcha, Liane Venturella (1964) é formada pela Desmond Jones School of Mime and Physical Theatre, em Londres. Aprimorou seus estudos na MIME School (Paris), Lorna Marshall e École Phillippe Gaulier. 
exercício de trabalhar a contramáscara, uma máscara que possui em suas expressões, linhas angulares que apontam para baixo - tanto na região dos olhos, boca e têmporas faciais - possibilita, a quem a observa, uma leitura de seus estados de ânimo fundamentais próximos a tristeza, calma, angustia ou apatia, dependendo do caráter de tais linhas. Ao escolher uma máscara com características expressivas bem definidas, o ator ou atriz que a porta, geralmente utiliza em seu jogo de atuação, registros corporais que vão ao encontro às linhas expressivas daquela máscara. Ou seja, no caso do exemplo citado, a corporeidade a ser explorada seria de uma pessoa com estados de ânimo próximos aos da máscara, sendo possível percebê-los por meio de seus usos corporais. $O$ trabalho de contramáscara, por sua vez, ocorre quando a pessoa portadora da máscara utiliza registros corporais de atuação não necessariamente alinhados com as expressões desta máscara, criando assim uma oposição entre linhas expressivas da máscara e linhas expressivas do corpo em jogo. Um exemplo neste caso, seria o da máscara com linhas angulares para baixo em estado de tristeza, apresentar em seu jogo de atuação qualidades corporais de alguém ágil, alegre ou até mesmo autoritário. Esse trabalho amplia as possibilidades de jogo, exercitando outras qualidades corporais para uma mesma máscara.

A partir deste trabalho de treinamento de atuação com a máscara expressiva, realizado no grupo Máscara EnCena - assim como em outros grupos e processos cênicos que utilizam a máscara como elemento pedagógico e artístico -, viu-se a necessidade de provocar o jogo do ator com a máscara por meio de situações reais e cotidianas, onde o contato com o público acontece de forma direta. Assim, a comunicação através da máscara e dos princípios de foco, interesse, ação, reação e triangulação, acontece de forma sutil por meio de suas reações musculares de qualidades de retração, expansão, peso e leveza, proporcionando diferentes leituras a partir do trabalho gestual do ator. Essa experiência despertou o desejo de aprofundar o jogo do ator com a Máscara Expressiva do tipo inteira no contato com a cultura urbana, de forma que as relações estabelecidas possibilitem afetações do ambiente por meio do jogo com a máscara, e deste jogo contaminar também o público, que, ao estabelecer contato com a linguagem gestual realizada pelo ator, também modifica a qualidade de suas ações na tentativa de estabelecer conexão com esta forma mascarada.

Acredito que a potência da máscara, assim como o jogo do ator em sua excelência, encontra-se na sua dimensão poética, de desconstruir o espaço e tempo ordinários com sua força imagética e expressiva de evidenciar a humanidade e suas fragilidades sob uma ótica diferente da que estamos habituados cotidianamente. Seu corpo inteiro fala, tece um outro tempo no espaço que outrora é de passagem. Essa ação na rua,, direcionada ao outro fala por meio do corpo, utilizando-se de uma linguagem gestual de tal forma que é preciso parar, observar o gesto e seu discurso. Nessa observação geralmente o público/transeunte para, silencia, interage. Ora ri, ora se afasta. Sente alegria, repulsa, medo, compaixão. Estímulos desencadeados através da corporeidade da máscara e seus mistérios. É um convite a um outro tempo materializado pelo corpo, exercitando nossa percepção de que aquilo que se vê é um corpo vivo em uma desconcertante dicotomia entre real e ficção, corpo e máscara, humano e não humano.

O ator que atua com máscara recebe desse objeto de papelão a realidade de sua 
personagem. É comandado por ela e a ela obedece irresistivelmente. Assim que a põe sente surgir nele uma existência de que [...] nem sequer suspeitava. Não é somente o seu rosto que se modifica, mas toda a sua pessoa, o próprio caráter dos seus reflexos, em que já se pré-formam sentimentos que ele era igualmente incapaz de experimentar e de fingir com o rosto descoberto. (Copeau apud Faleiro, 2009, p. 14-15)

A estrutura desta composição corporal - através da máscara expressiva e seus princípios - é capaz de possibilitar uma leitura clara da tipologia da personagem por meio de suas posturas e qualidades gestuais. Mas de onde vem essas expressões e suas representações se não das relações do cotidiano presentes também nas ruas? Essa corporeidade da máscara a partir do estudo e prática de seus princípios destaca-se dos corpos cotidianos por evidenciar seus mecanismos de ação, também presentes nos corpos dos transeuntes, porém de forma atenuada. Nesta relação entre corpos, importa menos ao espectador/transeunte identificar os princípios da máscara e sim a relação possível com este outro corpo em fluxo contínuo e orgânico. A técnica aqui - e em toda forma teatral - deve ser esquecida, ou seja, transcendida e não evidenciada, para que então o ator possa se relacionar cenicamente de forma orgânica, tendo assimilado os princípios técnicos anteriormente praticados. $O$ jogo, fruto dessa relação, fortalece a possibilidade de contato com a rua e sua cultura local. É no âmbito das relações banais que está o teatro. Ali vive a complexidade do humano, e o teatro (se) alimenta (d)isso. Nesse fluxo incessante das ruas, de passos apressados, buzinas, outdoors, ofertas promocionais e todo tipo de interferência visual, física, sonora - juntamente aos contrastes sociais - parar, escutar e observar é um movimento de contra fluxo. É neste espaço público - onde se estabelece cada vez mais uma função de transição do que de convívio - que a pluralidade habita, formando uma cultura urbana específica, que varia do centro urbano à periferia. Nestes diferentes contextos urbanos o ator desenvolve a ação dramática, que por meio das relações com as conjunturas ambientais, constrói sentido às suas ações ao mesmo tempo em que é também construído pelo espectador.

Neste contexto, e considerando o funcionamento da cidade em fragmentos, adquire um papel fundamental o comportamento dos cidadãos que cruzam um determinado território. As decisões tomadas por estes cidadãos quando se confrontam com uma performance teatral representam a mais incisiva ferramenta das dramaturgias da cidade reescrevendo a cena. $O$ espetáculo na rua é sempre reescrito pelas interferências das dinâmicas da cidade. O público flutuante - que caracteriza a recepção da cidade - impõe processos fragmentados e empilhamentos caóticos que são de fato uma das riquezas do espetáculo de rua. Este público é um elemento fundamental na própria definição do ambiente que se concretiza na construção social do espaço da cidade. (Carreira, 2009, p. 5) 


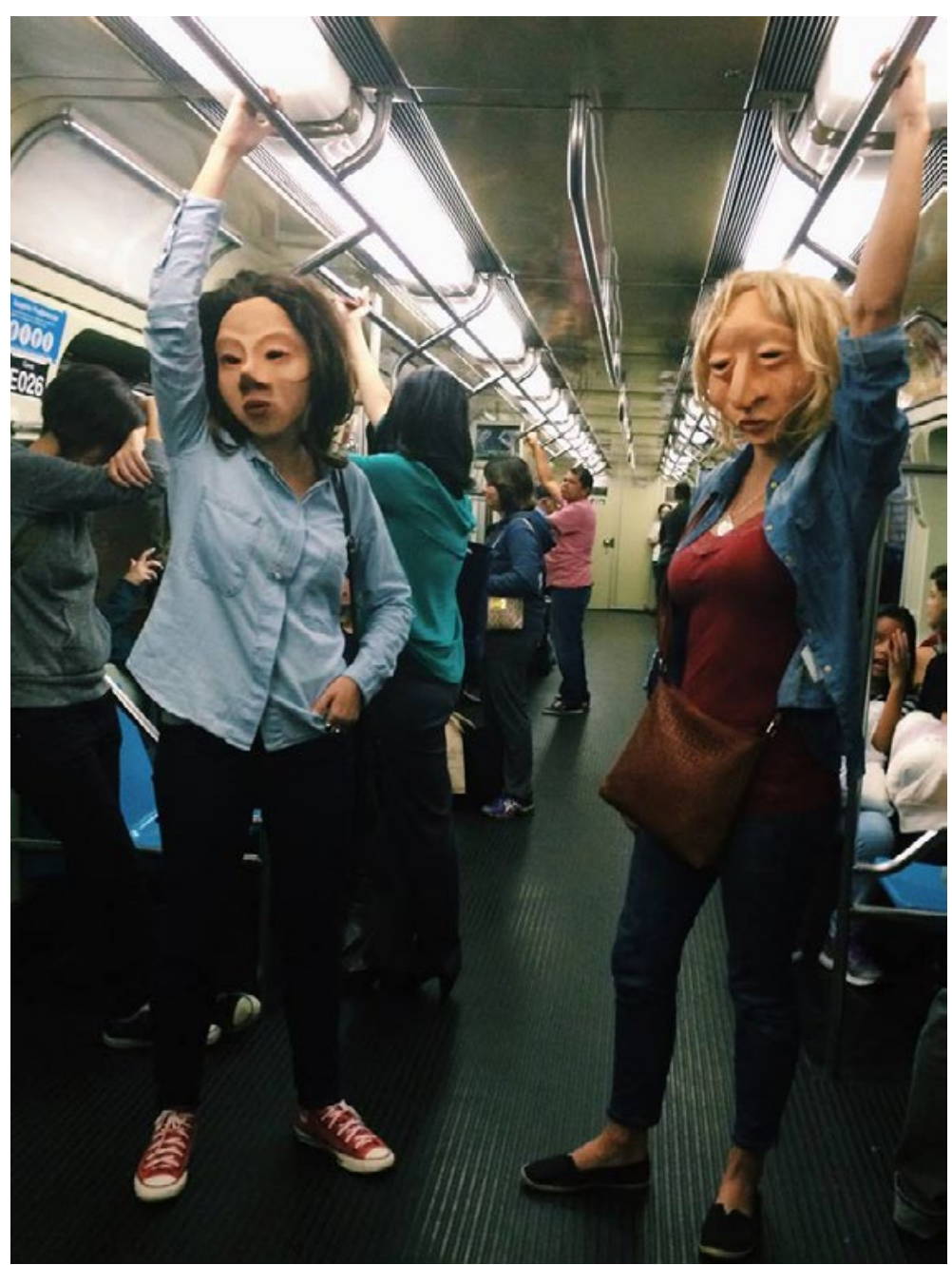

Intervenção com Máscaras Expressivas no metrô de São Paulo, 2015.

$\mathrm{Na}$ foto as atrizes Camila Vergara e Francine Kliemann. Foto: grupo Máscara EnCena.

A dramaturgia desse tipo de trabalho com a máscara sem a palavra falada - aqui entendida como a tessitura da ação dramática, não necessariamente vinculada à encenação, texto dramático ou criação de narrativa - é construída com o espectador, através dos elementos oferecidos pelos atores. Entretanto, existe uma construção de linguagem onde não há espaço para a pantomima ${ }^{18}$, mas sim para a impressão de diferentes tonicidades corpóreas, traduzidas na linguagem da máscara como estados, sempre em relação a algo ou alguém. São essas tonicidades que oferecerão sentido para o espectador construir sua própria narrativa. Nesse sentido, o trabalho da máscara, assim como na cena convencional, permite a emancipação do espectador, tal como reflete o filósofo Jacques Rancière em seu artigo intitulado $O$ Espectador Emancipado (2010) quando ele disserta sobre as implicações do teatro contemporâneo.

A emancipação parte do princípio oposto, o princípio da igualdade. Ela começa quando dispensamos a oposição entre olhar e agir e entendemos que a distribuição do próprio visível faz parte da configuração de dominação e sujeição. [...]. O espectador é ativo, assim como o aluno ou o cientista. Ele observa, ele seleciona,

\footnotetext{
18 Teatro gestual no qual se faz uso mínimo da palavra, onde situa-se a mímica. Também se compreende como pantomima gestos que descrevem algum acontecimento de forma ilustrativa. Diferente da codificação gramatical dos movimentos do corpo, estudada e desenvolvida pelo ator e profissional do mimo francês Etienne Decroux, a qual chamou de Mimo Corpóreo: prática gestual que implica o estudo das ações físicas, seus meios e forças de atuação do espaço.
} 
ele compara, ele interpreta. Ele conecta o que ele observa com muitas outras coisas que ele observou em outros palcos, em outros tipos de espaços. Ele faz o seu poema com o poema que é feito diante dele. Ele participa do espetáculo se for capaz de contar a sua própria história a respeito da história que está diante dele. Ou se for capaz de desfazer o espetáculo - por exemplo, negar a energia corporal que deve transmitir o aqui e agora e transformá-la em mera imagem, ao conectá-la com algo que leu num livro ou sonhou, viveu ou imaginou. (Rancière, 2007, p. 115)

O espectador se torna também poeta e inventor de sua dramaturgia juntamente com o ator, através dos signos expostos e da horizontalidade das relações. Aquilo que se vê é, mas também pode vir a ser. Sobrepondo sentido às definições propostas através da palavra e tecendo sua narrativa no espaço plural da rua. Essa proposta de investigar a atuação da máscara inteira expressiva na rua, vai ao encontro de uma abordagem de intervenção da máscara no ambiente urbano, sem o comprometimento de construir um espaço ou acontecimento cênico para uma encenação teatral.

É evidente que, em se tratando de uma ação cênica na rua, o ator está sujeito à inúmeros riscos, intervenções e obstáculos que uma sala de teatro não oferece: intervenções do público, buzinas, interferências sonoras e visuais, e até a abordagem policial e proibição da ação - prática cada vez mais comum nos centros urbanos brasileiros, visto o crescimento das políticas neoliberais e de exclusão, que assemelham-se, e muito, às práticas de patrulha do regime militar instaurado no Brasil em 1964 a 1985, mas que mantêm suas raízes vivas e atuantes ainda hoje. Dessa forma, na rua não basta estar atento aos riscos, mas sim defender o espaço atuante através de uma disponibilidade para o jogo: estar presente no ato do agora e em sua relação com a cidade e com tudo que circunda o ator. Neste exercício de jogar com a máscara inteira expressiva na rua, interessa a relação deste corpo com o mundo que o rodeia.

A cidade está em constante movimento, troca sua pele a todo momento e se reorganiza em microcidades de acordo com suas posições geográficas, domínios institucionais e de classe específicos, que imprimem regras igualmente distintas. Além disso, de um ponto de vista macroscópico e particular, a cidade tece uma narrativa, de acordo com o horário, períodos do dia, dias da semana e meses do ano, compondo uma estrutura convivial e uma rotina. A partir dessas noções, o teatro, a performance ou o elemento cênico se apropria da rua e com ela compõe acontecimentos de ordem poética no âmbito público.

Considerando o aspecto plural das ruas, são também plurais e distintas as fricções desses acontecimentos cênicos, que não se constituem indiferentemente aos usos sociais e culturais da cidade, mas sim junto a eles, inter(agindo) com eles e sobre eles. Dessa forma a cidade é construtora de sentido porque condiciona, através de seus constituintes, um funcionamento específico do dispositivo cênico de acordo com sua cultura urbana. Ela é estruturada e estruturante, pois a arquitetura, as ações dos transeuntes e os discursos institucionais interferem também em seu acontecimento.

Pensando nessa reescritura da ação do ator mascarado e em sua relação com o cidadão que ali transita, o processo de experimentação das possibilidades de jogo deve não somente partir dos princípios metodológicos da máscara expressiva anteriormente citados (foco, interesse, ação, reação e triangulação) - capazes de 
condicionar o corpo à qualidades como precisão de movimento, limpeza gestual, presença cênica e amplitude corporal -, mas também da observação e análise dessa cultura urbana: quem são as pessoas que ali transitam? A senhora que passeia com seu cãozinho; o estudante que sai da escola; o vendedor ambulante e suas mercadorias; o trabalhador que toma um cafezinho depois do almoço; o aposentado que joga xadrez no banco da praça; o morador de rua; o catador de lixo. Todos esses personagens compõem o espaço urbano, e são seus corpos e modos de ser sociais que mais tarde serão adaptados à linguagem e corpo da máscara. Essa linguagem se elabora com os elementos presentes na rua, buscando um diálogo da máscara com as diferentes realidades presentes nas cidades, principalmente nos grandes centros.

Nos centros urbanos das grandes cidades, a singularidade do indivíduo perde-se de vista e é arrastada para junto da massa, compondo um coletivo desconexo, que não se entende como tal em meio a tanta informação. As desigualdades sociais e seus reflexos acabam por serem normatizadas e se tornam cenário comum, não sendo atendidas pelo Estado - que tem esta obrigação - acabando por serem marginalizadas e esquecidas no seio social, como a situação dos moradores de rua. As mazelas de seus corpos já não chocam a quem passa, fazem parte da desintegração social presente no cotidiano da cidade. De fato, essa desintegração é um contraste diante da modernização e homogeneização das cidades, através de projetos urbanísticos que buscam seguir um modelo internacional de cidade com uma imagem próxima das grandes cidades mundiais, porém de realidades sociais cada vez mais díspares, criando uma gentrificação ${ }^{19}$ dessas áreas e seu entorno.

Este modelo visa basicamente o turista internacional - e não o habitante local - e exige um certo padrão mundial, um espaço urbano tipo, padronizado. Como já ocorre com os espaços padronizados das cadeias dos grandes hotéis internacionais, ou ainda dos aeroportos, das redes de fast food, dos shopping centers, dos parques temáticos ou dos condomínios fechados, que também fazem com que as grandes cidades mundiais se pareçam cada vez mais, como se formassem todas uma única imagem: paisagens urbanas idênticas (Berenstein Jacques, 2005, p. 17-18)

Considerando isso, com a máscara na rua, o ator pode coabitar com o fluxo urbano de forma a interferir em suas dinâmicas tradicionais através da inserção do elemento cênico na paisagem urbana, homogeneizada e higienizada. Sua natureza expressiva funciona também como um eixo pelo qual o cidadão/transeunte torna-se espectador, chamando a atenção para contextos sociais já naturalizados, e, portanto, invisíveis na paisagem urbana na qual se insere. Nesse sentido, referindo-se a intervenção como um conjunto de elementos cênicos não previstos no cenário urbano, prefiro utilizar o termo "ocupação" ao de invasão levando em conta que a rua é também um "palco tombado" ao acontecimento cênico e defendendo a ideia que esse espaço pertence também ao artista, que não invade, mas ocupa o espaço que lhe é de direito - embora as restrições às apresentações em espaços públicos sejam cada vez maiores, ocasionadas pelas políticas autoritárias que buscam censurar e

19 Elitização, expulsão da população mais pobre, termo desenvolvido por Neil Smith no livro intitulado The new urban frontier, gentrification and the revanchist city. Londres: Routledge, 1996. 
higienizar o convívio e a liberdade sociais.

Diante do fluxo urbano esse novo corpo torna-se visível e convida a atenção do transeunte por romper com os padrões corporais e temporais do cotidiano, criando uma conjuntura poética inesperada diante do espectador. Possibilitando uma ruptura, um estranhamento que permite a pausa, a interrupção, suspensão do tempo, da respiração e do trajeto seguido pela pessoa que passa, revelando talvez outro olhar sobre o que normalmente não é visto com atenção, em relação aos outros e ao seu entorno.

Com a ideia de mostrar as suas paixões e de agir com a máscara, o ator ocupa a rua e preenche com detalhes o emaranhado turbulento da cidade. Esse detalhe deve ser pensado com requintes de poesia por meio dos princípios próprios do trabalho com a máscara, e não ser uma exteriorização apenas, mas um processo vivo e presente, onde o ator está constantemente buscando alcançar a complexidade e grandiosidade de uma máscara e sua relação, e não apenas animando-a de forma ilustrativa. Elas brindam o presente e exigem a disciplina necessária ao ator na busca da sinceridade de seu jogo, afim de explorar suas capacidades corporais e expressivas. As personagens que passam a existir através da máscara possuem o potencial de reter aquilo que é efêmero e comum a todo humano, além de evidenciar e possibilitar outra visibilidade aos indivíduos, assim como aos ambientes e situações com os quais se relaciona, revelando a essência da dinâmica da cidade e sua complexidade.

\section{Referências}

BAKHTIN, Mikhail. A Cultura Popular na Idade Média e no Renascimento - O contexto de François Rabelais. São Paulo: Editora Hucitec, 1987.

BERENSTEIN JACQUES, Paola. Errâncias urbanas: a arte de andar pela cidade. Revista Arqtexto. N. 7 - Programa de Pesquisa e Pós-Graduação em Arquitetura (UFRGS). Porto Alegre, 2005.

CARREIRA, André. Ambiente, Fluxo e Dramaturgias da cidade: materiais do Teatro de Invasão. O Percevejo - Periódico do Programa de Pós-Graduação em Artes Cênicas PPGAC/UNIRIO. V. 1. F. 1: Rio de Janeiro, 2009.

FALEIRO, José Ronaldo. Copeau e a Máscara. Urdimento - Revista de Estudos em Artes Cênicas. N. 12. Programa de Pós-graduação em Teatro (UDESC). Florianópolis, 2009.

FERRACINI, Renato. A Arte de não interpretar como Poesia Corpórea do Ator. Campinas: Imprensa Oficial, 2001.

FÉRAL, Josette. Encontros com Ariane Mnouchkine - Erguendo um monumento ao efêmero. São Paulo: Editora Senac e Sesc, 2010.

LECOQ, Jacques. O Corpo Poético - uma pedagogia da criação teatral. São Paulo: Editora Senac, 2010. 
MAGALDI, Sábato. Teatro da Obsessão: Nelson Rodrigues. São Paulo: Global Editora, 2004.

RANCIÈRE, Jacques. O Espectador Emancipado. Urdimento - Revista de Estudos em Artes Cênicas. N. 15. Programa de Pós-graduação em Teatro (UDESC). Florianópolis, 2010.

VIANNA, Tiche. Para além da commedia dell'arte - a máscara e sua pedagogia / Beatriz Maria Vianna Rosa. SP/Campinas, [s.n.], 2017.

\section{Referênciais encontrados na Internet}

ROLIM, Michele. Teatro Jornal - Leituras de Cena: Bufão do Século XIX. Disponível em: http://teatrojornal.com.br/2014/06/bufao-do-seculo-xix/. Acesso em: 13 jun. 2018.

BRAVO, Hellen. WHITAKER, Fábio. Desvendando Teatro - Gêneros: Farsa ou Farsesco. Disponível em: http://www.desvendandoteatro.com/gneros.htm. Acesso em: 13 jun. 2018.

LOPES, Wagner. A Morte da Morte. Abrindo Página Editora. Rio de Janeiro: 2013. Disponível em: https://books.google.com.br/books?isbn=8566276094. Acesso em: 10 jun. 2018.

ROCHA, Helder da. A Serpente: síntese e símbolos. Disponível em: http://www.helderdarocha.com.br/sections/performing_arts/pt/teatro_old/nelson/serpente/A_ Serpente.pdf. Acesso em: 13 jun. 2018.

SMITH, Neil. The new urban frontier, gentrification and the revanchist city. Disponível em: http://rohcavamaintenant.free.fr/USB\%20KEY\%20Fahriye/k\%C4\%B1tap\%20 Neil\%20Smith__The_New_Urban_Frontier__Gentrification_and_the_Revanchist_ City.pdf. Acesso em: 15 dez. 2017.

Recebido em: 24/01/2018

Aprovado em: 17/06/2018 